\title{
MAPS AND FIGURES
}

\section{MAPS}

Map I. Brazil in the 19th Century $x x$

Map 2. Brazil in $1855 \quad I 60$

Map 3. Paraguayan War-The Paraguayan offensives, I864-65 20I

Map 4. Paraguayan War-The course of the war, I866-70 218

\section{GENEALOGICAL TABLES}

Table I. The Ancestry of Pedro II 8

Table 2. Selected descendants of Pedro I, emperor of Brazil 23

Table 3. Selected descendants of Ferdinand IV, king of Naples 87

Table 4. Selected descendants of Louis-Philippe, King of the French

Table 5. The principal branches of the House of Saxe-Coburg-Gotha

\section{FIGURES}

Frontispiece. Pedro II in the first half of the I850s ii

Figure I. Pedro II's mother, Empress Leopoldina 6

Figure 2. Pedro II's father, Emperor Pedro I, in I826 7

Figure 3. The Paço da Cidade (city palace) at the time of Independence I3

Figure 4. Pedro II's eldest sister, Queen Maria II of Portugal I6

Figure 5. Pedro II at the age of four 2I

Figure 6. Pedro II's stepmother, D. Amélia of Leuchtenberg 26

Figure 7. José Bonifácio de Andrada e Silva, Pedro II’s guardian, I83I-33 35

Figure 8. Pedro II at the age of six, wearing the farda imperial (court dress) 40

Figure 9. Paulo Barbosa da Silva, mordomo of the imperial court, I833-68 50

Figure Io. Pedro II with his sisters D. Francisca and D. Januária in I835 53

Figure II. Pedro II at about the age of eleven or twelve 63

Figure I2. Aureliano de Sousa e Oliveira Coutinho, viscount of Sepetiba 77

Figure 13. Official portrait of Princess Teresa Cristina of Naples 9I

Figure I4. Pedro II and D. Teresa Cristina at the time of their wedding 98

Figure I5. Honório Hermeto Carneiro Leão, marquis of Paraná IoI

Figure i6. Pedro II at about twenty-one or twenty-two IIo 
Figure 17. The imperial palace at Petrópolis II5

Figure I8. São Cristóvão Palace in the mid-nineteenth century II8

Figure 19. D. Teresa Cristina in court dress, at about the age of thirty $\quad$ I27

Figure 20. Pedro II at the age of twenty-four $\quad$ I29

Figure 2I. Pedro II in I858 I35

Figure 22. View of Pedro II’s study at São Cristóvão Palace $\quad$ I37

Figure 23. D. Isabel and D. Leopoldina in about I856 I45

Figure 24. Pedro II, with D. Teresa Cristina, teaching their daughters in I860 I46

Figure 25. Luísa Margarida Portugal de Barros, countess of Barral $\quad$ I47

Figure 26. Maria Eugênia Lopes de Paiva, Sra. Guedes, and later Sra. Jones I49

Figure 27. D. Isabel and her husband, Gaston d'Orléans, count d'Eu $\quad{ }_{156}$

Figure 28. D. Leopoldina and her husband, August of Saxe-Coburg-Gotha $\quad 157$

Figure 29. Luís Alves de Lima, duke of Caxias I7I

Figure 30. Pencil sketch made by Pedro II while conducting business $\quad$ I75

Figure 3I. Teófilo Benedito Ottoni $\quad 189$

Figure 32. Statue of Pedro I, inaugurated in April I862 190

Figure 33. Pedro II in the early I860s I9I

Figure 34. Zacarias de Góis e Vasconcelos 196

Figure 35. Pedro II in the uniform of a Voluntário da Pátria 203

Figure 36. Gaston, count d'Eu, in uniform 207

Figure 37. Pedro de Araújo Lima, marquis of Olinda 209

Figure 38. Gaston, count d'Eu, commander-in-chief of the Brazilian forces in Paraguay, with his staff 229

Figure 39. D. Isabel at about the time of her first regency, I87I-72 237

Figure 40. Pedro II at the pyramids in Egypt in November I87I 239

Figure 4I. Cristiano Benedito Ottoni 242

Figure 42. José Maria da Silva Paranhos, viscount of Rio Branco 249

Figure 43. D. Vital Maria Gonçalves de Oliveira, bishop of Olinda 255

Figure 44. João Maurício Wanderley, baron of Cotegipe 260

Figure 45. D. Isabel with her first child, Pedro, prince of Grão Pará 272

Figure 46. Pedro II photographed in New York, I876 278

Figure 47. Luís Pedreira do Couto Ferraz, viscount of Bom Retiro 28I

Figure 48. D. Teresa Cristina photographed at Coburg in I876 or I877 283

Figure 49. José Antônio Saraiva 295

Figure 50. Pedro II in the late I870s or early I880s 300 
Figure 5I. João Lustosa da Cunha Paranaguá, marquis of Paranaguá 3 I0

Figure 52. Caricature of Pedro II in a popular review early in I887 330

Figure 53. D. Isabel at the time of her third regency, I887-88 336

Figure 54. Pedro II’s oldest grandson, Pedro Augusto 340

Figure 55. Pedro II, returning from Europe in August I888 343

Figure 56. Pedro II and his family at Petrópolis in I889 345

Figure 57. Afonso Celso de Assis Figueiredo, viscount of Ouro Preto 35I

Figure 58. Manuel Deodoro da Fonseca, founder of the republic 354

Figure 59. Pedro II, D. Isabel, and her eldest son, Pedro, April I89I 379

Figure 60. Tombs of Pedro II, D. Teresa Cristina, D. Isabel, and Gaston, count d'Eu in the cathedral at Petrópolis $4 \mathrm{IO}$ 